\title{
PENGARUH GOOD CORPORATE GOVERNANCE TERHADAP KINERJA DAN NILAI PERUSAHAAN (STUDI PADA PERUSAHAAN YANG TERINDEKS OLEH CGPI)
}

\author{
Eva Maria Sulastri; Dian Hakip Nurdiansyah \\ Email: hakipnurdiansyah@staff.unsika.ac.id
}

\begin{abstract}
Abstrak
Penelitian ini bertujuan untuk menganalisis pengaruh good corporate governance terhadap kinerja perusahaan dan nilai perusahaan yang dapat dijadikan acuan manajemen dalam menggunakan tata kelola yang baik dan tepat sehingga dapat menguntungkan perusahaan secara keseluruhan.

Populasi pada penelitian ini menggunakan seluruh perusahaan yang terdaftar di Bursa Efek Indonesia dengan sampel perusahaan yang masuk dalam indeks CGPI dengan jumlah sampel 91 perusahaan. Variabel yang digunakan pada penelitian ini yaitu good corporate governance yang diproksikan dengan CGPI, kinerja perusahaan yang menggunakan proksi Return On Assets (ROA) dan Return On Equity (ROE), sedangkan nilai perusahaan menggunakan TOBIN'S Q dan Market to Book Value (MBVR). Penelitian ini menggunakan alat analisis regresi linear yang berfungsi untuk mengetahui pengaruh antara good corporate governance, kinerja perusahaan dan nilai perusahaan.

Hasil dari penelitian ini menunjukkan bahwa good corporate governance berpengaruh positif signifikan terhadap kinerja perusahaan, good corporate governance berpengaruh positif signifikan terhadap nilai perusahaan yang diproksikan dengan MBVR sedangkan jika diproksikan dengan TOBIN'S Q tidak berpengaruh, pengaruh kinerja perusahaan terhadap nilai perusahaan memberikan beberapa hasil, ROA berpengaruh positif signifikan terhadap TOBIN'S Q kemudian ROE tidak berpengaruh terhadap TOBIN'S Q dan ROA serta ROE tidak berpengaruh terhadap MBVR.
\end{abstract}

Kata Kunci: good corporate governance, return on assets, return on equity, TOBIN'S Q dan market to book value

\section{PENDAHULUAN}

Nilai perusahaan adalah suatu tujuan jangka panjang perusahaan yang dapat dilihat dari harga per sahamnya karena merupakan suatu penilaian investor terhadap perusahaan yang dapat diamati melalui pergerakan harga saham perusahaan yang ditransaksikan di bursa untuk perusahan yang sudah go public. Pentingnya nilai perusahaan digunakan untuk mengetahui bagaimana keadaan perusahaan tersebut dan menentukan minat para investor untuk mengivestasikan dana mereka di perusahaan tersebut. Nilai tersebut dapat dilihat dengan harga saham perusahaan tersebut. Keadaan harga saham perusahaan yang stabil dapat mengindikasikan bahwa keadaan perusahaan tersebut baik dan sejalan dengan nilai perusahaan tersebut.

Beberapa faktor yang mempengaruhi nilai perusahaan yaitu diantaranya dipengaruhi oleh kinerja perusahaan dan good corporate governance. Kinerja perusahaan dapat diartikan sebagai suatu hasil dari suatu proses kegiatan perusahaan yang dapat dilihat melalui beberapa tolok ukur pada laporan keuangan. Pada umumnya kinerja perusahaan 
dapat diukur dari tingkat profitabilitas perusahaan yang diantaranya dapat dilihat dari proksi Return On Asset (ROA) dan Return On Equity (ROE). Karena tingkat profitabilitas adalah tolok ukur yang digunakan investor untuk mengetahui keadaan keuangan suatu perusahaan.

Selain faktor kinerja keuangan perusahaan, faktor lain yang mempengaruhi nilai perusahaan yaitu corporate governance yang baik. Menurut IICG (The Indonesian Institute for Corporate Governance) bahwa konsep corporate governance sebagai serangkaian mekanisme untuk mengarahkan dan mengendalikan suatu perusahaan agar operasional perusahaan berjalan sesuai dengan harapan stakeholders. Corporate governance yang baik sebagai struktur, sistem, dan proses yang digunakan oleh organ-organ perusahaan sebagai usaha untuk memberikan nilai tambah perusahaan secara berkelanjutan. Adanya GCG (Good Corporate Governance) atau praktik tata kelola perusahaan diperlukan untuk pengawasan khususnya di sektor keuangan di suatu perusahaan yang berfungsi untuk menciptakan suatu sistem keuangan yang sehat secara fundamental dan berkelanjutan serta untuk melindungi kepentingan konsumen dan masyarakat (Otoritas Jasa Keuangan, 2014).

Diterapkan corporate governance yang baik bertujuan untuk meningkatkan kinerja perusahaan yang nantinya akan meningkatkan nilai perusahaan secara keseluruhan yang meliputi stakeholders, karyawan dan perusahaan itu sendiri. Perusahaan yang telah menerapkan corporate governance yang baik dapat terlihat dari cara menyeimbangkan berbagai kepentingan pihak-pihak yang terdapat dalam suatu perusahaan, sehingga dapat memberikan keuntungan bagi perusahaan secara menyeluruh. Karena adanya corporate governance yang baik akan mengurangi konflik keagenan antara pihak manajemen dan agen yang mempunyai tujuan yang berbeda. Meminimalisir konflik keagenan tersebut, tentunya juga akan berdampak pada keuntungan bagi perusahaan secara menyeluruh dengan meningkatnya nilai perusahaan yang dapat dilihat dari harga saham perusahaan tersebut.

Adanya ketidaksesuai penerapan corporate governance yang baik, tentunya akan berdampak buruk pada tata kelola perusahaan tersebut. Di Indonesia terdapat kasus good corporate governance yaitu Bank Indonesia (BI) memberikan sanksi kepada empat bank. Keempat bank tersebut diantaranya adalah PT. Bank Mega Tbk, PT. Bank Panin Tbk, PT. Bank Jabar Banten Tbk, dan PT. Bank Mestika Dharma. Sanksi tersebut diberikan oleh Bank Indonesia, dikarenakan keempat bank tersebut tidak menerapkan Good Corporate Governance (GCG). Sanksi yang diberikan oleh Bank Indonesia terhadap keempat bank tersebut berbeda, sesuai dengan apa yang mereka lakukan.

Terkait persoalan Bank Mega yaitu hilangnya sejumlah deposito milik Elnusa dan Pemerintah Kabupaten Batubara, total dana yang hilang sebesar Rp 191 miliar, dengan rincian dana Elnusa Rp 111 miliar dan Pemkab Batubara Rp 80 miliar. Untuk kasus Elnusa sudah berlangsung hingga ke ranah hukum, dan sekarang dalam tahap kasasi di Mahkamah Agung.

Untuk persoalan dari Bank Jabar Banten yaitu terdapat tiga kasus. Pertama terkait dengan dana Koperasi Bina Usaha sebesar Rp 38 miliar yang dinilai BI terjadi lantaran tidak menerapkan GCG. Kedua terkait dengan pembangunan tower BJB di wilayah Jakarta sebesar Rp 540 miliar yang sudah ditangani oleh KPK. Sedangkan yang ketiga terkait dengan kredit di Surabaya yang sudah ditangani oleh Kejaksaan Agung.

Untuk Bank Panin terdapat dua kasus. Pertama mengenai take over ANZ yang sudah berjanji menjadi pemegang saham pengendali, tapi sampai sekarang belum ada hasilnya. Hingga kini ANZ memiliki saham lebih dari 25 persen, tapi ANZ berubah pikiran dan akan mendivestasikannya. Kedua tentang pegawai Bank Panin yang terkena 
Pemutusan Hubungan Kerja (PHK) dan untuk hal ini Bank Indonesia meminta kepada Bank Panin menyelesaikannya secara internal.

Sedangkan kasus yang terjadi di Bank Mestika Dharma mengenai agunan seorang nasabah yang bernama Krisyanto sebesar Rp 1,2 miliar. Hingga kini kasus tersebut masih diawasi oleh Bank Indonesia. Selain keempat bank tersebut, terdapat dua bank. Pertama, Bank Danamon cabang Depok terdapat nasabah yang awalnya memiliki uang Rp 43 miliar, tapi belakangan dananya diketahui tinggal $\mathrm{Rp}$ 6000, nasabah tersebut merasa dirugikan karena tidak pernah mengambil uang, akan tetapi brkurang banyak. Kedua, Bank Permata yang didapati pegawai diturunkan jabatannya karena produktifitas kinerjanya menurun karena menjadi calon legislatif.

Berdasarkan fenomena yang terjadi di atas penting penerapan corporate governance yang baik dan kinerja perusahaan yang maksimal akan mempengaruhi bagaimana nilai perusahaan tersebut dihasilkan dan menarik untuk diamati oleh investor sehingga memberikan motivasi untuk penulis melakukan penelitian dari tata kelola perusahaan dan kinerja perusahaan terhadap nilai perusahaan. Purwanti (2010) yang meneliti dengan sampel seluruh perusahaan yang terdaftar di Bursa Efek Indonesia dan termasuk dalam peserta survey The Indonesian Institute for Corporate Governance (IICG) selama periode tahun 2004 sampai dengan tahun 2008 dan hanya terdapat 89 perusahan yang sesuai dengan kriteria pemilihan yang menyimpulkan bahwa good corporate governance tidak berpengaruh secara langsung terhadap kinerja perusahaan dengan proksi EVA, dapat dilihat bahwa secara simultan berpengaruh positif signifikan sedangkan secara parsial tidak berpengaruh positif signifikan.

Retno M. dan Priantinah (2012) meneliti dengan pengambilan sampel perusahaan yang terdaftar di BEI pada periode 2007-2010 yang menyimpulkan bahwa good corporate governance berpengaruh positif terhadap nilai perusahaan, pengungkapan CSR tidak berpengaruh terhadap nilai perusahaan, dan secara simultan good corporate governance serta pengungkapan CSR berpengaruh positif terhadap nilai perusahaan. Tertius dan Christiawan (2015) meneliti dengan sampel perusahaan sektor keuangan pada tahun 20112013 yang menyimpulkan bahwa secara simultan dewan komisaris, komisaris independen, kepemilikan manajerial, dan ukuran perusahaan mempengaruhi ROA, sedangkan secara parsial dewan komisaris dan kepemilikan manajerial tidak berpengaruh terhadap ROA, sedangkan komisaris independen dan ukuran perusahaan berpengaruh secara negatif dan signifikan terhadap ROA. Berdasarkan latar belakang permasalahan di atas, maka penelitian ini ingin meneliti secara empiris beberapa pertanyaan sebagai berikut:

1. Apakah Good Corporate Governance berpengaruh terhadap kinerja perusahaan?

2. Apakah kinerja perusahaan berpengaruh terhadap nilai perusahaan?

3. Apakah Good Corporate Governance berpengaruh terhadap nilai perusahaan?

\section{KAJIAN TEORI DAN PENGEMBANGAN HIPOTESIS}

\subsection{Teori Keagenan}

Perusahaan adalah suatu pusat perjanjian kontrak antara berbagai pihak yang masingmasing mempunyai kepentingan berbeda, yaitu pemegang saham, manajemen yang diwakili oleh manajer, supplier dan pihak-pihak lainnya termasuk calon investor dan karyawan (Baskoro dan Wardhani, 2014 : 4). Hubungan antara berbagai pihak yaitu antara principal atau pemegang saham dan agen atau manajemen dapat dijelaskan melalui teori keagenan. Adanya permasalahan yang timbul dari konflik antara pemilik dan manajer merupakan landasan dari munculnya teori keagenan. Agen yaitu pihak manajer dan principal yaitu pihak pemilik merupakan dua pihak yang masing-masing memiliki tujuan 
berbeda dalam mengendalikan perusahaan terutama menyangkut bagaimana memaksimumkan kepuasan dan kepentingan dari hasil yang dicapai melalui aktivitas usaha (Tjager, 2003).

Menurut Jensen dan Meckling (1976) dalam Putu (2008) mendefinisikan suatu hubungan keagenan sebagai suatu kontrak atas satu orang atau lebih (principal). Dalam hal ini, principal memberikan beberapa kewenangan kepada agen untuk mengambil keputusan. Adanya keleluasaan dari pihak agen, memberikan ruang untuk melakukan penyelewangan yang tidak sesuai dengan keinginan pihak principal. Oleh karena itu, pihak principal membatasi agen dengan cara menetapkan insentif. Dari penjelasan di atas, dapat disimpulkan bahwa teori keagenan adalah hubungan antara pihak principal dan agen dengan masing-masing memiliki tujuan berbeda, sehingga adanya perbedaan tersebut memunculkan konflik keagenan antara kedua belah pihak.

Teori keagenan berlaku terhadap kegiatan manajemen dalam pembuatan keputusan akan investasi di mana manajer yang berperan sebagai agen tersebut melakukan kebijakan untuk mengelola investasi perusahaan pada tahun berjalan sebagai perwakilan dari para pemegang saham sebagai principal (Baskoro dan Wardhani, 2014 : 5). Oleh karena itu, untuk meminimalisir adanya konflik antara manajer dan pemilik dibutuhkan biaya keagenan yang dikeluarkan oleh pemilik agar manajer dapat melakukan kegiatan sesuai dengan keinginan pemilik, dapat melalui bonus atau insentif yang diberikan.

\subsection{Good Corporate Governance}

Good corporate governance merupakan sebuah sistem tata kelola perusahaan yang berisi seperangkat peraturan yang mengatur hubungan antara pemegang saham, pengurus (pengelola) perusahaan, pihak kreditur, pemerintah, karyawan, serta para pemegang kepentingan intern dan ekstern lainnya dalam kaitannya dengan hak-hak dan kewajiban mereka atau dengan kata lain, suatu sistem yang mengatur dan mengendalikan perusahaan, dengan tujuan untuk meningkatkan nilai tambah (value added) bagi semua pihak yang berkepentingan. Jika pelaksanaan good corporatre governance tersebut berjalan dengan efektif dan efisien, maka seluruh proses aktivitas perusahaan akan berjalan dengan baik, sehingga hal-hal yang berkaitan dengan kinerja perusahaan baik yang sifatnya kinerja finansial atau non finansial akan juga ikut membaik (Brown and Caylor, 2004 dalam Purwani, 2010:51). Menurut Forum for Corporate Governance in Indonesia (FCGI), (2001:2), corporate governance diartikan sebagai seperangkat peraturan yang mengatur hubungan antara pemegang, pengurus, (pengelola) perusahaan, pihak kreditur, pemerintah, karyawan, serta para pemegang kepentingan internal dan eksternal lainnya yang berkaitan dengan hak-hak dan kewajiban mereka atau dengan kata lain suatu sistem yang mengendalikan perusahaan. Prinsip-prinsip utama dari Good Corporate Governance yaitu (Purwani, 2012: 52-53):

a. Transparency (Transparansi): dalam menjalankan fungsinya, semua partisipan menyampaikan informasi yang material sesuai dengan substansi yang sesungguhnya dan menjadikan informasi tersebut dapat diakses dan dipahami secara mudah oleh pihak-pihak lain yang berkepentingan.

b. Accountability (Pertanggungjawaban): dalam menjalankan fungsinya, setiap partisipan corporate governance harus mempertanggungjawabkan amanah yang diterima sesuai dengan hukum, peraturan, standar moral dan etika, maupun best practice yang berterima umum.

c. Responsiveness (Ketanggapan): dalam menjalankan fungsinya, setiap partisipan corporate governance harus tanggap dan antisipatif terhadap permintaan (request) 
maupun umpan balik (feedback) dari pihak-pihak yang berkepentingan dan terhadap perubahan dunia usaha yang berpengaruh signifikan terhadap perusahaan.

d. Independency (Independensi): dalam menjalankan fungsinya, setiap partisipan harus bebas dari kepentingan pihak-pihak lain yang berpotensi memunculkan konflik kepentingan dan menjalankan fungsinya sesuai dengan kompetensi yang memadai.

e. Fairness (Keadilan): dalam menjalankan fungsinya, setiap partisipan memperlakukan pihak lain berdasarkan ketentuan-ketentuan yang berterima umum secara adil.

\subsection{Kinerja Perusahaan}

Kinerja perusahaan yaitu hasil kerja yang dapat dicapai oleh seseorang atau kelompok orang dalam suatu perusahaan sesuai dengan wewenang dan tanggung jawab masing-masing dalam upaya pencapaian tujuan perusahaan secara legal, tidak melanggar hukum dan tidak bertentangan dengan moral dan etika (Rivai dan Basri, 2004:16). Kinerja merupakan salah satu faktor yang menunjukkan efektifitas dan efisiensi suatu organisasi dalam rangka mencapai tujuannya. Efektifitas terjadi apabila manajemen memiliki kemampuan untuk memilih tujuan yang tepat atau suatu alat yang tepat untuk mencapai tujuan yang telah ditetapkan. Sedangkan efisiensi diartikan sebagai rasio (perbandingan) antara masukan dan keluaran yaitu dengan masukan tertentu memperoleh keluaran yang optimal.

Menurut Kamus Besar Bahasa Indonesia (1995), kinerja dapat diartikan sebagai sesuatu yang dapat dicapai, prestasi yang diperlihatkan dan kemampuan kerja, berkinerja artinya berkemampuan dengan menggunakan tenaga. Sehingga dapat disimpulkan bahwa kinerja perusahaan biasanya dapat dilihat dari bagaimana tingkat profitabilitas yang dihasilkan oleh perusahaan tersebut, apabila tingkat profitabilitas tinggi maka akan memperlihatkan bahwa kinerja perusahaan tersebut baik, begitu juga sebaliknya guna mencapai tujuan atau prestasi suatu perusahaan.

Nilai Perusahaan

Menurut Andri dan Hanung (2007) dalam Nica Febrina (2010 : 5), nilai perusahaan adalah nilai jual perusahaan atau nilai tumbuh bagi pemegang saham, nilai perusahaan akan tercermin dari harga pasar sahamnya. Nilai perusahaan menurut Rika dan Islahudin (2008) dalam Retno M. dan Priantinah (2012 : 86) mengartikan sebagai nilai pasar. Nilai perusahaan merupakan suatu kondisi tertentu yang sudah didapatkan oleh suatu perusahaan sebagai gambaran dari kepercayaan masyarakat terhadap perusahaan setelah melalui suatu proses kegiatan selama beberapa tahun, yaitu sejak perusahaan tersebut didirikan sampai saat ini. Meningkatknya nilai perusahaan adalah sebuah prestasi yang sesuai dengan keinginan para pemiliknya, karena dengan meningkatknya nilai perusahaan, maka akan meningkatkan kesejahteraan para pemilik perusahaan tersebut.

Nilai perusahaan dapat memberikan kemakmuran pemegang saham secara maksimum apabila harga saham perusahaan meningkat. Semakin tinggi harga saham, maka semakin tinggi kemakmuran pemegang saham. Sehingga besar kecilnya nilai perusahaan sangatlah penting bagi kelangsungan hidup suatu perusahaan. Apabila harga saham perusahaan tersebut turun, tentunya akan berdampak pada menurunnya nilai perusahaan dan tentunya akan dirasakan oleh semua pihak terkait yang memiliki kepentingan di perusahaan tersebut. Untuk mencapai nilai perusahaan umumnya para pemodal menyerahkan pengelolaannya kepada para profesional. Para profesional diposisikan sebagai manajer atau komisaris.

\subsection{Good Corporate Governance terhadap Kinerja Perusahaan}


Tata kelola suatu perusahaan yang baik tentunya akan berakibat pada meningkatnya kinerja perusahaan yang dihasilkan. Pada umumnya perusahaan yang menerapkan good corporate governance dengan baik secara teoritis dapat meningkatkan kinerja keuangan mereka. Kinerja perusahaan merupakan suatu gambaran dari sejauh mana keseriusannya menerapkan good corporate governance. Kinerja perusahaan sangat mendukung dengan diterapkannya prinsip-prinsip corporate governance yang baik (Budiman, 2004). Hal ini juga sesuai dengan hipotesis yang diungkapkan dalam penelitian Siahaan (2008) yang menyatakan bahwa terdapat hubungan positif antara penerapan good corporate governance dengan peningkatan kinerja perusahaan. Berdasarkan uraian di atas, maka hipotesis dalam penelitian ini dapat dikembangkan sebagai berikut:

$\mathrm{H}_{1}$ : Good Corporate Governance berpengaruh positif signifikan terhadap kinerja perusahaan

\subsection{Kinerja Perusahaan terhadap Nilai Perusahaan}

Kinerja perusahaan adalah suatu gambaran yang dapat dilihat oleh investor bagaimana keadaan perusahaan tersebut dapat dikatakan baik atau tidak. Pada umumnya kinerja perusahaan dapat diamati oleh investor untuk mengetahui bagaimana keadaan profitabilitas perusahaan tersebut apakah dapat dikatakan baik atau tidak. Kinerja perusahaan yang baik, otomatis akan meningkatkan nilai perusahaan, peningkatan tersebut terjadi dari informasi-informasi positif dari investor atau perusahaan tersebut yang membuat harga saham perusahaan tersebut naik. Pengukuran kinerja perusahaan merupakan salah satu indikator yang digunakan oleh investor untuk menilai suatu perusahaan dari harga saham tersebut di Bursa Efek Indonesia, semakin tinggi kinerja perusahaan, maka semakin tinggi nilai perusahaan. (Mahendra $\mathrm{Dj}, 2011$ : 6). Menurut Rozeff, 1982), menyatakan bahwa kinerja perusahaan yang dianggap semakin baik, dan pada akhirnya penilaian terhadap perusahaan akan terlihat melalui harga saham yang juga semakin baik. Berdasarkan uraian di atas, maka hipotesis dalam penelitian ini dapat dikembangkan sebagai berikut:

$\mathrm{H}_{2}$ : Kinerja perusahaan berpengaruh positif signifikan terhadap nilai perusahaan

\subsection{Good Corporate Governance terhadap Nilai Perusahaan}

Tata kelola perusahaan yang baik tentunya akan menaikkan nilai suatu perusahaan. Dengan adanya tata kelola perusahaan yang baik maka akan menyeimbangkan kepentingan berbagai pihak yang ada di dalam perusahaan agar dapat sesuai dengan tujuan dan menguntungkan perusahaan secara keseluruhan. Corporate governance yang baik dan diutamakan oleh perusahaan akan menaikkan nilai perusahaan secara keseluruhan. Pada penelitian yang dilakukan oleh Retno M. dan Priantinah (2012) menyatakan bahwa good coporate governance berpengaruh positif terhadap nilai perusahaan. Hubungan antara good corporate governance dengan nilai perusahaan dapat dilihat dari pernyataan Institute of Corporate Governance (IICG, 2006) sebagaimana diadopsi dari Cadbury Committee of United Kingdom, sebagai berikut: "The objective of corporate governance is to create added value to stakeholder". Berdasarkan uraian di atas, maka hipotesis dalam penelitian ini dapat dikembangkan sebagai berikut:

$\mathrm{H}_{3}$ : Good Corporate Governance berpengaruh positif signifikan terhadap nilai perusahaan

\section{METODE PENELITIAN}

Penelitian ini menggunakan populasi seluruh perusahaan yang terdaftar di Bursa Efek Indonesia selama tahun 2010-2014. Sedangkan sampel yang digunakan yaitu 
perusahaan yang masuk dalam indeks CGPI selama tahun 2010-2014. Dari keterangan di atas diperoleh 91 perusahaan sampel yang akan digunakan sebagai sumber analisis.

\subsection{Variabel Penelitian}

\subsubsection{Good Corporate Governance}

Perhitungan dari good corporate governance dapat dicari melalui indeks CGPI yang didalamnya sudah adalah pemeringkat perusahaan yang telah menerapkan good corporate governance yang disesuaikan dengan kriteria tertentu.

\subsubsection{Kinerja Perusahaan}

Kinerja perusahaan pada penelitian ini dapat diproksikan dengan Return On Asset dan Return On Equity. Berikut rumus yang digunakan untuk menghitung ROA, yaitu:

Return On Asset $=\frac{\text { Laba Bersih Sebelum Pajak }}{\text { Total Aktiva }}$

Sedangkan untuk menghitung ROE menggunakan rumus, yaitu:

\subsubsection{Nilai Perusahaan}

Return On Equity $=\frac{\text { Laba Bersih Setelah Pajak }}{\text { Total Ekuitas }}$

Nilai perusahaan pada penelitian ini dihitung dengan dua proksi yaitu TOBIN'S Q dan MBVR. Berikut rumus yang digunakan untuk mengitung Tobin's Q, yaitu:

Tobin's $Q=\frac{\text { Book Value Debt }+ \text { Market Value Equity }}{\text { Total Aset }}$

Sedangkan untuk menghitung Market to Book Value (MBVR), yaitu:

MBVR $=\frac{\text { Market Value Equity }}{\text { Book Value Equity }}$

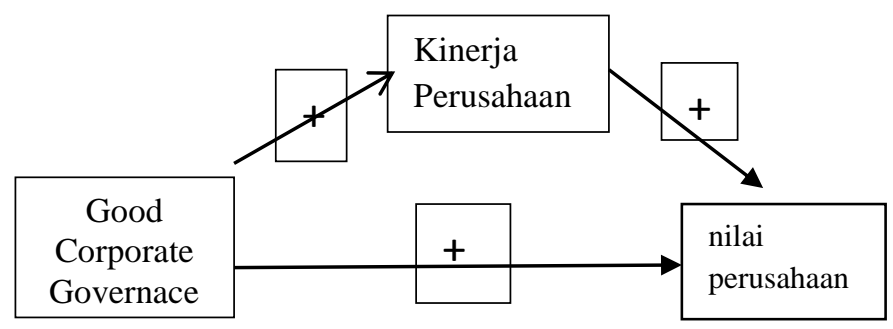

Nilai

Perusahaan

\section{HASIL PENELITIAN DAN PEMBAHASAN}

4.1 ANALISIS DATA

Statistik Deskriptif

\begin{tabular}{|l|l|l|l|l|}
\hline & Minimum & Maximum & Mean & Std. Deviation \\
\hline CGPI & 66.44 & 92.88 & 82.5179 & 6.39236 \\
\hline ROA & -0.35 & 0.27 & 0.0463 & 0.08979 \\
\hline ROE & -0.35 & 0.29 & 0.0513 & 0.09384 \\
\hline MBVR & 1.10 & 13.02 & 6.1110 & 3.40293 \\
\hline TOBIN'S Q & 0.19 & 6.33 & 1.5307 & 0.98263 \\
\hline
\end{tabular}

Variabel CGPI memiliki nilai terendah sebesar 66.44 dan nilai tertinggi sebesar 92.88 dengan rata-rata sebesar 82.5179 dengan persebarannya sebesar 6.39236. Pada variabel ROA memiliki nilai terendah sebesar -0.35 dan nilai tertinggi 0.27 dengan ratarata 0.0463 dengan persebarannya sebesar 0.08979. Pada variabel ROE memiliki nilai terendah -0.35 dan nilai tertinggi sebesar 0.29 dengan rata-rata sebesar 0.0513 dan persebarannya sebesar 0.09384. Pada variabel MBVR memiliki nilai terendah sebesar 1.10 dan nilai tertinggi sebesar 13.02 dengan rata-rata sebesar 6.1110 dan persebarannya 
sebesar 3.40293. kemudian pada variabel TOBIN'S Q memiliki nilai terendah sebesar 0.19 dan nilai tertinggi sebesar 6.33 dengan rata-rata sebesar 1.5307 dan persebarannya sebesar 0.98263 .

Analisis Regresi

Dalam penelitian ini menggunakan analisis regresi linear yang digunakan untuk mengetahui pengaruh GCG terhadap kinerja perusahaan dan nilai perusahaan. Model persamaan regresi linear adalah sebagai berikut:

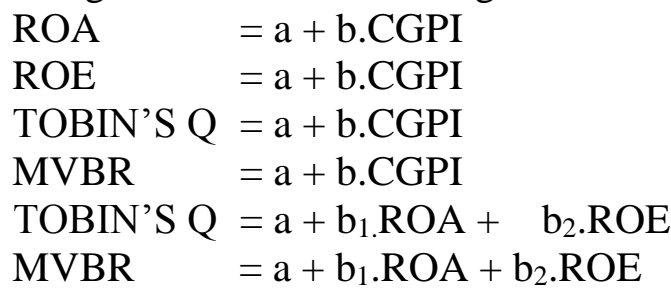

\subsection{Hasil Analisis Regresi}

\begin{tabular}{|c|c|c|c|c|}
\hline & Beta & $\mathrm{t}$ & $\begin{array}{l}\mathrm{P} / \\
\text { Sig }\end{array}$ & $\overline{\mathrm{R}^{2}}$ \\
\hline $\begin{array}{l}\mathrm{CGPI} \longrightarrow \\
\mathrm{ROA}\end{array}$ & 0.298 & 2.946 & 0.004 & 0.079 \\
\hline $\begin{array}{l}\mathrm{CGPI} \longrightarrow \\
\mathrm{ROE}\end{array}$ & 0.260 & 2.539 & 0.013 & 0.057 \\
\hline $\begin{array}{l}\text { CGPI } \rightarrow \\
\text { TOBIN'S } \\
\mathrm{Q}\end{array}$ & $\begin{array}{c}- \\
0.001\end{array}$ & $\begin{array}{c}- \\
0.010\end{array}$ & 0.992 & $\begin{array}{c}- \\
0.011\end{array}$ \\
\hline $\begin{array}{l}\mathrm{CGPI} \rightarrow \\
\mathrm{MBVR}\end{array}$ & 0.325 & 3.219 & 0.002 & 0.095 \\
\hline ROA & 0.980 & 4.335 & 0.000 & 0.376 \\
\hline \multicolumn{2}{|c|}{$\rightarrow$ TOBIN'S Q } & - & & \\
\hline ROE & 0.402 & 1.785 & 0.078 & \\
\hline ROA & 0.033 & 0.127 & 0.899 & 0.007 \\
\hline MBV & & & & \\
\hline ROE & 0.201 & 0.763 & 0.448 & \\
\hline
\end{tabular}

Good Corporate Governance terhadap Kinerja Perusahaan

Hipotesis pertama yang diajukan menyatakan bahwa good corporate governance berpengaruh positif signifikan terhadap kinerja perusahaan. Dari hasil penelitian ini menunjukkan bahwa good corporate governance berpengaruh positif signifikan terhadap kinerja perusahaan. Dalam penelitian ini, kinerja perusahaan dihitung dengan 2 proksi yaitu Return On Assets dan Return On Equity. Pada hasil proksi yang menggunakan ROA, CGC berpengaruh positif terhadap ROA dengan $p$ value sebesar 0.004 kurang dari alpha yaitu 0.05. sedangkan menggunakan proksi ROE, CGC berpengaruh positif signifikan terhadap ROE dengan $p$ value sebesar 0.013 kurang dari alpha yaitu 0.05. Hasil tersebut sesuai dengan penelitian yang dilakukan oleh Purwani (2012) yang menyatakan bahwa good corporate governance berpengaruh positif terhadap kinerja perusahaan. Sehingga 
dapat dilihat bahwa perusahaan yang menerapkan corporate governance yang baik akan menaikkan kinerja perusahaan secara keseluruhan.

Kinerja Perusahaan terhadap Nilai Perusahaan

Hipotesis kedua yang diajukan menyatakan bahwa kinerja perusahaan berpengaruh positif signifikan terhadap nilai perusahaan. Pada penelitian ini kinerja perusahaan diproksikan dengan ROA dan ROE sedangkan nilai perusahaan diproksikan dengan menggunakan TOBIN'S Q dan MBVR. Pada pengujian pertama, pengaruh ROA terhadap TOBIN'S Q menunjukkan $p$ value sebesar 0.000 kurang dari alpha 0.05 sehingga ROA berpengaruh positif signifikan terhadap TOBIN'S Q. sedangkan ROE tidak berpengaruh terhadap TOBIN'S Q yang ditunjukkan dengan $p$ value sebesar 0.078 yang lebih besar dari alpha sebesar 0.05. Kemudian ROA dan ROE tidak berpengaruh terhadap MBVR yang diperlihatkan dengan masing-masing $p$ value sebesar 0.899 dan 0.448 yang lebih besar dari alpha yaitu 0.05. Pada penelitian ini menunjukkaan bahwa kinerja perusahaan yang diproksikan dengan ROA dan nilai perusahaan yang diproksikan dengan TOBIN'S Q mempunyai pengaruh positif signifikan, sehingga hasil penelitian tersebut sesuai dengan penelitian yang dilakukan oleh Mahendra DJ (2011) yang menyatakan bahwa profitabilitas berpengaruh positif signifikan terhadap nilai perusahaan.

\subsection{Good Corporate Governance terhadap Nilai Perusahaan}

Hipotesis ketiga yang diajukan menyatakan bahwa good corporate governance berpengaruh positif signifikan terhadap nilai perusahaan. Dalam penelitian ini, nilai perusahaan menggunakan dua proksi yaitu TOBIN'S Q dan MBVR. Pada pengujian pertama, CGC yang diproksikan dengan CGPI tidak berpengaruh terhadap TOBIN'S Q yang ditunjukkan dengan hasil $p$ value sebesar 0.992 yang lebih besar dari alpha yaitu 0.05. Sedangkan pengujian yang kedua memperlihatkan bahwa CGPI berpengaruh positif signifikan terhadap MBVR yang ditunjukkan dengan hasil $p$ value 0.002 yang lebih kecil dari alpha yaitu 0.05 . Hasil pada penelitian ini yang menyatakan bahwa good corporate governance berpengaruh positif signifikan terhadap nilai perusahaan yang diproksikan dengan MBVR yaitu sesuai dengan penelitian yang dilakukan oleh Retno M. dan Priantinah (2012) yang menyatakan bahwa GCG berpengaruh positif signifikan terhadap nilai perusahaan. Sehingga dapat dijelaskan bahwa perusahaan yang telah menerapkan corporate governance yang baik akan meningkatkan nilai perusahaan tersebut.

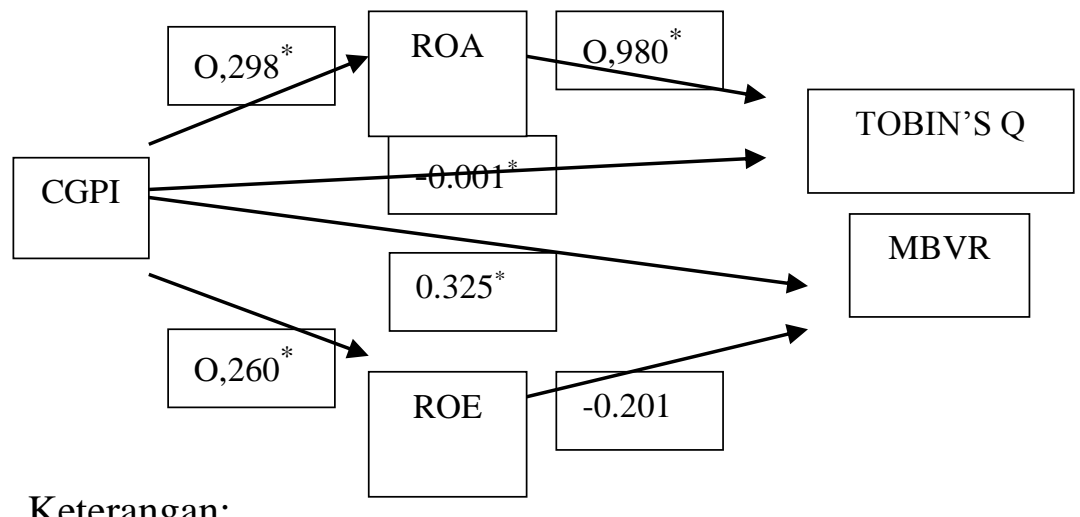

Keterangan:

$(*)=p$ value $<0.05$ 


\section{KESIMPULAN DAN SARAN}

Penelitian ini bertujuan untuk menguji pengaruh good corporate governance terhadap kinerja perusahaan, pengaruh kinerja perusahaan terhadap nilai perusahaan dan pengaruh good corporate governance terhadap nilai perusahaan pada perusahaan yang terdaftar di Bursa Efek Indonesia dan masuk kriteria Indeks CGI. Berdasarkan hasil penelitian diketahui bahwa CGPI berpengaruh positif signifikan terhadap ROA, CGIP berpengaruh positif signifikan terhadap ROE, CGIP tidak berpengaruh terhadap TOBIN'S Q, CGIP berpengaruh positif signifikan terhadap MBVR, ROA berpengaruh positif terhadap TOBIN'S Q, ROE tidak berpengaruh terhadap TOBIN'S Q, ROA dan ROE tidak berpengaruh terhadap MBVR.

Dilihat dari hasil penelitian tersebut menjelaskan bahwa perusahaan memang perlu untuk menerapkan corporate governance yang baik, karena sudah dibuktikan bahwa perusahaan yang memiliki corporate governance yang baik akan meningkatkan kinerja perusahaan dan nilai perusahaan, dan tentunya hal tersebut menguntungkan berbagai pihak secara keseluruhan. Sehingga penting untuk perusahaan yang belum menerapkan corporate governance yang baik agar segera menerapkannya dan perusahaan yang sudah menerapkan konsep corporate governance yang baik untuk senantiasa melakukan peningkatan secara berkelanjutan.

\section{REKOMENDASI}

Untuk peneliti selanjutnya sebaiknya periode yang digunakan untuk mengambil sampel dapat ditambah atau diperluas pada sektor perusahaan yang lain. Kemudian bagi peneliti selanjutnya, diharapkan dapat menambah variabel-variabel lain yang tentunya terkait dengan penelitian tersebut, sehingga dapat memperoleh hasil yang lebih rinci mewakili keadaan yang sebenarnya.

\section{DAFTAR PUSTAKA}

Baskoro, Mahardhika Prasetyadi dan Wardhani, Ratna. (2004). Analisis Pengaruh Volatilitas Laba dan Manajemen Laba Riil dan Akrual Terhadap Kebijakan Investasi. SNA 17 Mataram, Lombok Universitas Mataram. Hal 1-27.

Brown, Lawrence and J., Caylor. (2004). Corporate Governance and Firm Performance. Boston Accounting Research Colloquium 15 th.

Budiman, Cipta. (2004). Analisis Kinerja Keuangan Pada Perusahaan Publik di Bursa Efek Jakarta dengan Menggunakan Pendekatan Economic Value Added. (Thesis yang tidak dipublikasikan.

Bukhori, Iqbal. (2012). Pengaruh Good Corporate Governance dan Ukuran Perusahaan Terhadap Kinerja Perusahaan (Studi Empiris Pada Perusaah yang Terdaftar di BEI 2010). Skripsi Universitar Diponegoro.

Febrina, Nica. (2010). Pengaruh Komisaris Independen dan Kinerja Keuangan Terhadap Nilai Perusahaan (Studi Empiris Pada Perusahaan Wholesale yang Terdaftar di Bursa Efek Indonesia). Jurnal Jurusan Manajemen Fakultas Ekonomi Universitas Gunadarma 
Jensen, Michael C. and Meckling, William H. (1976). Theory of the Firm: Managerial Behaviour, Agency Costs and Ownership Structure. Journal of Financial, Vol. 3, No.4, pp 305-360.

Kumar, Jayesh. (2004). Does Corporate Governance Influence Firm Value? Evidence from Indian Firms. The Journal of Enterpreneurial Finance, Vol. 9, Iss. 2, pp 61-92.

Mahendra DJ, Alfredo. (2011). Pengaruh Kinerja Keuangan Terhadap Nilai Perusahaan (Kebijakan Dividen Sebagai Variabel Moderating) Pada Perusahaan Manufaktur di Bursa Efek Indonesia). Thesis Program Magister Jurusan Manajemen Universitas Udayana Denpasar.

Otoritas Jasa Keuangan. (2014). Roadmap Tata Kelola Perusahaan Indonesia Menuju Tata Kelola Emiten dan Perusahaan yang Lebih baik.

Pambudi, Januar Eky dan Sumantri, Farid Addy. (2014). Kualitas Audit, Ukuran Perusahaan dan Leverage Terhadap Manajemen Laba. SNA 17 Mataram, Lombok, Universitas Mataram.

Purwani, Tri. (2010). Pengaruh Good Corporate Governance Terhadap Kinerja Perusahaan. Majalah Ilmiah INFORMATIKA, Vol. 1, No.2, hal 47-60.

Tjager, I. Nyoman. (2003). Corporate Governance. Pearson Education Asia.

Tertius, Melia Agustina dan Christiawan, Yulius Jogi. (2015). Pengaruh Good Corporate Governance Terhadap Kinerja Perusahaan Pada Sektor Keuangan. Business Accounting Review, Vol. 3,No. 1, hal 223-232.

Retno M, Reny Dyah dan Priantinah, Denies. (2012). Pengaruh Good Corporate Governance dan Pengungkapan Corporate Social Responsibility Terhadap Nilai Perusahaan (Studi Empiris Pada Perusahaan yang Terdaftar di Bursa Efek Indonesia Periode 2007-2010). Jurnal Nominal, Vol.1, No.1, hal 84-103 